\title{
皮革関連産業構造の変遷から見た台東区北部地域の地域産業空間構造 地域産業空間構造から見た都市部職住混在空間の実態と継承に関する研究その 1 \\ REGIONAL-INDUSTRIAL STRUCTURE IN NORTHERN TAITO-WARD FROM THE VIEWPOINT OF TRANSITION OF LEATHER INDUSTRY
}

A study on the fact and inheritance of urban Residential-Industrial mixed-use area from the view of Regional-Industrial structure Part1

演田 愛*1, 中島直人*2, 西村幸夫*3 Megumi HAMADA, Naoto NAKAJIMA and Yukio NISHIMURA

\begin{abstract}
Northern Taito Ward is an area where the leather industry has located from early modern times. To incorporate the perspective of industrial structure with the discussion on the mixed-use spaces, this study disclosed the regional-industrial structure from the viewpoint of transition of leather industry.

In 1970, establishments located separately depending on the industrial positions, and there had been high-density business relationships inside the area. Although there was no major change in the total number of leather establishments from that time, location of establishments tends to be distributed, and commercialization has occurred in the whole area.
\end{abstract}

Keymords: U rban industry, Industrial spaces, Leather industry, Taito-Ward, Residential-Industrial mixed use, Regional structure 都市産業，産業空間，皮革産業，台東区，職住混在，地域構造

1. はじめに

\section{1. 研究の背景と目的}

高度成長期の市街地拡大による住宅地開発や工場・製造空間の分 離政策を経験してきた都市部の既存市街地では、その後の人口の空 洞化現象と都心回帰に伴い、マンション開発や再開発などの大規模 な空間変容が進んでいる。それらの開発と高齢化などによる人口構 成の急激な変化の結果、現在都市部では固有の都市空間や地域組織 などの崩壊の問題が顕在化しつつある。また、我が国のグローバル 化と成熟化に伴い、産業構造が脱工業化し消費社会へと変化しつつ ある中で、既存の製造業においては事業継承難や工場跡地などの問 題が発生している。都市部における従来の地場産業地域では、都市 機能維持のため如何にして生活空間と産業空間を融合させていくか、 持続可能な産業都市空間が問われている。(野原、2009)

そこで本研究では持続可能な産業都市空間形成に向け、近世より 伝統的に職住混在空間が維持・形成されてきた都市部の小規模地場 産業集積地域である台東区北部皮革関連産業集積地に着目し、(1) 1970 年当時の産業構造別の立地並びに取引関係を明らかにし、エリ ア内に形成されていた地域産業空間構造を復元すること、(2)加えて、 資料が少ない現代における皮革関連産業事業所の基礎デー夕を作成
すること、(3)それら 2 時点のデータを比較することにより近代化並 びに脱工業化に伴う事業所の構成並びに立地の変化の実態を産業構 造の視点から捉え台東区北部の地域空間構造の形成プロセスを明ら かにすること、の 3 点を目的とした分析を実施する。

\section{2. 台東区皮革産業における議論の系譜と本研究の位置付け}

台東区の皮革関連産業集積地における議論は、エリア間(東京都) スケールの立地論など空間と結びついた議論と、継承されている地 場産業の事例として産業振興を目的とした産業ネットワーク並びに 産業支援など空間に結びついていないシステム的な議論に分けるこ とができる。

前者の地域構造と絡めた議論は主に 1960-1970 年代の経済地理 学の分野を中心として、それまでの機能配置的な用途地域指定に対 する問題提起として行われてきた。井出(1966)は城東地域における 日用消費財工業が同心円状の地域機能分化的な立地を示すことが述 べている。また、竹内ら（1963）はそのような東京都の工業分布の 全体把握と併せた各業種の把握の一環として、東京都における製革 業地域の立地変動及び形成過程に関する研究を実施している。その 後足立区本木における皮革工業と家具工業に関する考察が大谷 (1973)によって実施されており、産業構造上での浅草(台東区)との

\footnotetext{
*1 東京大学大学院工学系研究科都市工学専攻 博士課程 $\cdot$ 工修

*2 東京大学大学院工学系研究科都市工学専攻 准教授 $\cdot$ 工博

*3 神戸芸術工科大学大学院芸術工学研究科 教授・工博
}

Grad. Student, Dept. of Urban Engineering, School of Engineering, The University of Tokyo, M.Eng.

Assoc. Prof., Dept. of Urban Engineering, School of Engineering, The University of Tokyo, Dr.Eng.

Prof., Graduate school of Kobe Design University, Dr.Eng. 
関係を示し、零細工業としての性格をもつ皮革工業下職部門が再生 産されるメカニズム及び産業立地を明らかにしている。

後者の産業構造並びに産業振興支援における議論では、貿易自由 化などに伴い産業構造が多品種少量生産型へと大きく変化した 2000 年代以降に再び注目されており、産業支援によるネットワーク 形成と地域アイデンティティの構築（山本、2005）や、若手人材育 成（高橋、2013）などが評価されるようになってきた。また、宮寺 （2015）による研究では、浅草地域の革製履物製造業の衰退につい て着目し、製造業を司る従事者が経営者層と職人層の 2 つのレイヤ 一に分けられ、現在置かれる環境や今後の展望に違いが生じている ことを指摘している。

本研究は主に前者の地域産業空間構造を読み解く観点に立ち、か つて同心円状の「住・商・工」の混在立地が報告されていた台東区 北部において、地域内部における詳細な地域産業構造の実態及びそ の変化を皮革関連産業構造の視点からエリアスケールで分析し、現 在の実態及び今後の論点を整理するものである。脱工業化が進んだ と考えられる 1970 年から現代までの変化を空間に即して追う点、 面的な分析だけでなく事業所の立地や詳細な取引関係など地域内部 の視点から実態に即した都市空間の考察を行う点に新規性がある。

\section{3. 研究の方法}

本研究では、a)統計調査、b) 1970 年の事業所名によるエリア内の 取引関係の照合、c)現代における事業所リスト作成、d)事業所リスト の住所と住宅地図の照合による立地分析、の 3 つの分析を実施した。

a）統計調查では、主に経済産業省平成 26 年度「工業統計」にお ける統計情報を用いた対象地の皮革関連産業事業所実態の整 理を実施した。主に第 2 章において使用寸る。

b) 1970 年の取引関係の照合は「靴産業名鑑 1970 年版」に挙げら れている取引先事業所の名称を照合させ、エリア内で Face to Face で行われていたと予想される取引関係の実態を明らかに した。注1)主に第 2 章において使用する。

c）タウンページなどのデータをもとに、現代における台東区皮革 関連産業事業所を抽出し、事業所名・住所・電話番号・部門注 2) の項目で 370 件の事業所リストを作成した。主に第 4 章におい て使用する。

d） 1970 年の靴産業名鑑における事業所並びに現代において作成 した事業所リストの住所と住宅地図を照合させてプロット注 3) し、産業部門とエリア内における立地の傾向を可視化した。主 に第 4 章において使用する。

\section{4. 用語の定義}

本研究において「地域産業空間構造」とは、機能・取引のネット ワークシステムとしての「産業構造」に、一定のエリア内における 空間的な展開まで含めた概念として使用する。

\section{2. 東京都における皮革関連産業と台東区北部地域の位置付け}

\section{1 . 東京都皮革関連産業の位置付け}

まず、全国から見た東京都の皮革産業の位置付けを試みる。Fig. 1 は品目群「なめし革・同製品・毛皮」の都道府県別の出荷額を示寸。 皮革関連の製品は首都圈及び関四圈を中心として多く出荷されてお り、大消費地立地型の産業であると言える。グラフより特に東京都 及び兵庫県における生産額が突出し、また事業所数も全国の 2 割程
度を占めていることから、東京都は我が国の皮革関連産業の主要な 集積地の一つであることがわかる。

次に東京都の皮革産業の特性を整理する。同じく平成 26 年工業 統計の品目名を元に、東京都及び兵庫県の製造品目の出荷額の分布 を調查したものをFig. 2 に示す。東京都の皮革産業は、牛皮と比心゙ ると比較的小規模かつ回転が速いといった特徽を持つ豚皮の取扱が 多いことを特徵とし、革製履物や小物等の 2 次的な加工業も大きな シェアを占めている。次に Fig. 3 では、東京都における「なめし革・ 同製品・毛皮製造業」の区別事業所数を示す。本産業は都内では、 城東エリアと呼ばれる北東地域を中心として集積しており、特に台 東区・墨田区・足立区が生産額・事業所数ともに上位を占めている。

最後に、東京都における台東区の位置付けを行う。産業中分類「な めし革・同製品・毛皮製造業」の中の小分類の東京都内における事 業所数の区別割合をFig. 4 に整理した。これにより、原材料加工で ある「なめし革」の製造は主に墨田区で行われているのに対し、革 製品の加工業は台東区・足立区 (主に革製履物は台東、袋物は足立) で多く集積していることがわかる。既往研究などで唱えられている ように、東京都内の集積地においても、産業構造上の位置付けによ る広域的な分業体型が確立されていることが分かる。

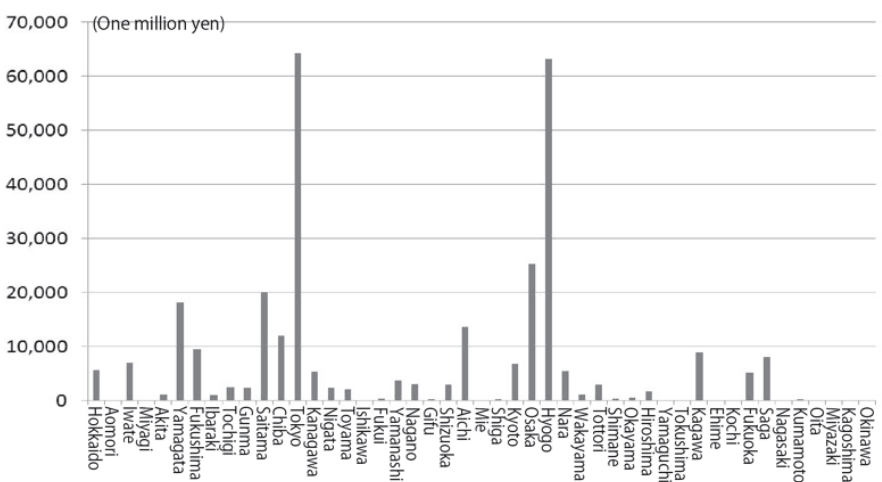

Fig. 1 Shipment value of prefecture of middle industry classificaton “tanning leather. same product. fur” ; million yen (H26 エ業統計より作成)

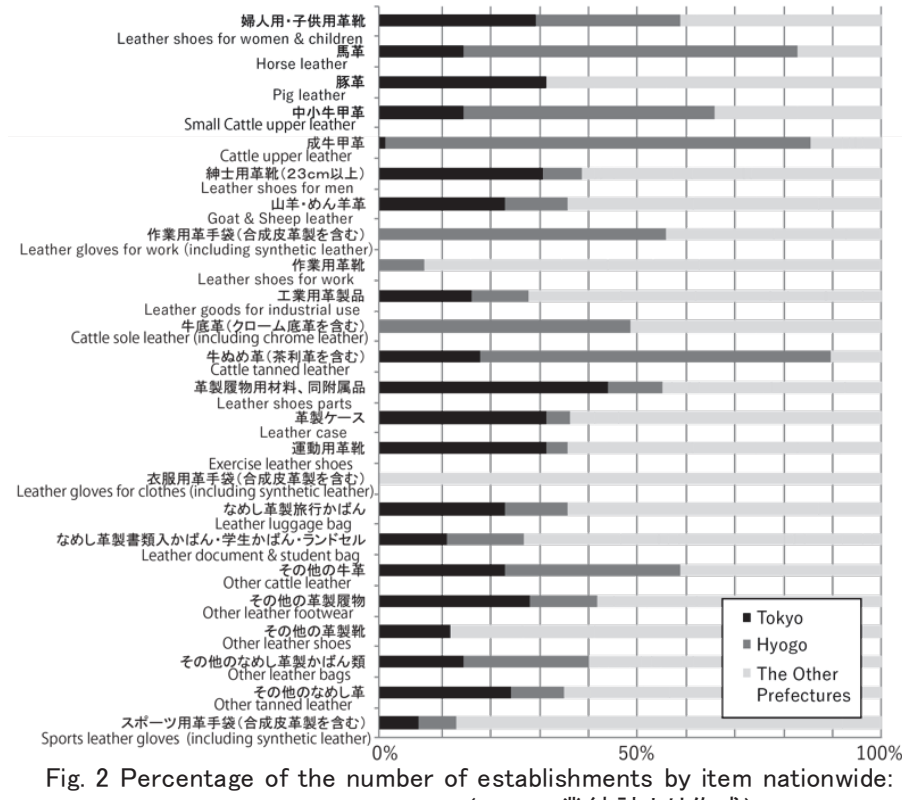

Focusing on Tokyo \& Hyogo Pref. (H26 工業統計より作成) 


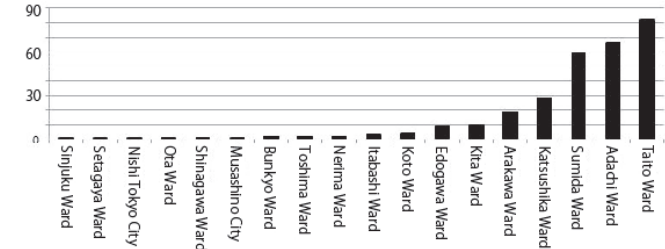

Fig. 3 Number of Establishments classified in "Tanning Leather \& Products / Fur Manufacturing Industry" in the Middle Industry Classification by District in Tokyo (H26 工業統計より作成)

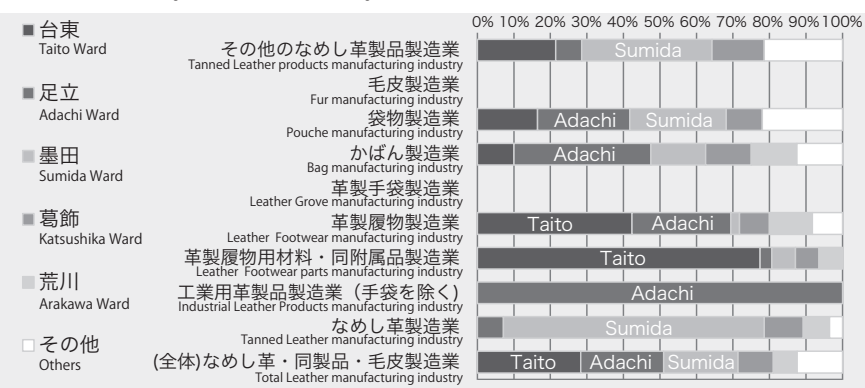

Fig. 4 Rate of Establishments numbers in Sub-classification of "Leather, Same Product, Fur” by Region in Tokyo (H26 工業統計より作成)

\section{2. 皮革関連産業の産業構造とその変遷}

主に本研究の対象地に集積している靴産業を中心に、皮革製品加 工業における流通構造を整理する。皮革製品加工業の流通構造に関 しては、袋物製造業も含めると、竹内ら (1963) を始めとして井出 (1966)、大谷 (1973)、山本 (2005)、下村 (2015)など地理学および都 市社会学の分野においてその産業ネットワーク関係が示されている。 それらの既往研究をもとに作成した皮革関連産業の取引ネットワー ク関係及び本研究の対象範囲を Fig. 5 に示す。

「製造卸」であるメーカーが、下請けとしての材料屋及び加工工 程の事業者を統括している構造となっている。メーカーは卸問屋か ら受注した企画に従って、各材料屋から製品パーツを購入し、それ をそれぞれの工程の加工業者へと外注し回収した後、最終的な組立 作業を自社で行い出荷する。現在は、縫製などの加工部門の海外・ 東京外一の流出が激しい一方で、材料屋や裁断などの機械化し生産 効率化した工程などは近距離に立地していることも報告されている。 また、メーカーにおいては企画・技術力を有する起業と問屋依存か ら脱却できない企業の二分化傾向があり、今後の方向性として国内 における高付加価值生産には限界があるため企画力の向上及び産地 外との取引ネットワークの構築が課題とされている。

皮革・靴関連産業においては、産業全体として衰退してきている ものの、依然としてこれらの産業構造が比較的保たれているものと 考えられる。注 4 )

Table 1 The Numbers of 1970 Dealings Inside the Taito-ku between Leather Industrial Companies（1970 年「靴産業名鑑」より抽出）

\begin{tabular}{|c|c|c|c|}
\hline \multicolumn{4}{|c|}{ Number of leather and shoe industrial company inside Taito-Ward in 1969} \\
\hline $\begin{array}{l}\text { 全国靴製造業者 } \\
\text { Manufacturer }\end{array}$ & $\begin{array}{l}\text { 全国靴卸業者 } \\
\text { Wholesaler }\end{array}$ & $\begin{array}{c}\text { 皮革の製造販売 } \\
\text { Manufacture \& sale of leather }\end{array}$ & $\begin{array}{c}\text { 付属材料 } \\
\text { Shoe parts company }\end{array}$ \\
\hline 222 & 85 & 66 & $\begin{array}{l}44 \\
\text { include } 2 \text { Manufacture \& sale of leather companies ,6 } \\
\text { wholesaler companies. }\end{array}$ \\
\hline \multicolumn{2}{|c|}{ Suppliers of shoe manufacturers inside Taito ward } & \multicolumn{2}{|c|}{ Sales destination of shoe manufacturers inside Taito ward } \\
\hline Inside Taito ward/All in Tokyo & $300 / 499$ (about $60 \%$ ) & Inside Taito ward/All in Tokyo & $277 / 556$ (about $50 \%$ ) \\
\hline From Manufacturer in the ward & 3 & To Manufacturer in the ward & 16 \\
\hline From Wholesaler in the ward & 5 & To Wholesaler in the ward & 260 \\
\hline From Manufacture \& sale of leather in the ward & 279 & To Manufacture \& sale of leather in the ward & 0 \\
\hline From Shoe parts company in the ward & 13 & To Shoe parts company in the ward & 1 \\
\hline
\end{tabular}

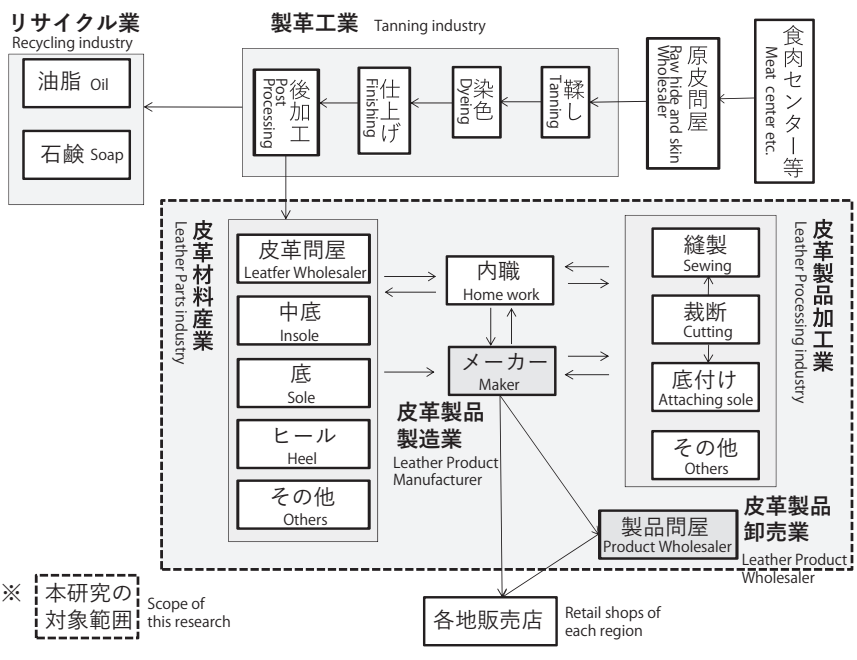

Fig. 5 Distribution Structure of Leather Product Processing Industry; Focusing on Shoes Industry（既往研究を元に筆者作成）

\section{3. 1970 年代における産業ネットワーク及び調査対象の選定}

\subsection{1.エリア内取引関係の把握}

ここで、上記の産業構造上の対象範囲と対象エリアである台東区 北部との対応性を調查する。実証方法は、1970 年の靴産業名鑑を用 いて、「全国靴製造業者」「全国靴卸業者」「皮革の製造販売」「付属 材料」における台東区内の事業所を抽出し、エリア内における取引 関係を把握した。結果をTable. 1 に示す。

以上の結果より、製造業者を中心とした取引は、大きく捉えると 「皮革製造販売」 $\rightarrow$ 「製造」 $\rightarrow$ 「卸」という流れが形成されていた ことが確認できた。また、製造業者を中心とした全取引の半数以上 の高い割合で、エリア内においてネットワークが形成されていたこ とが判明した。

\section{3. 2. ネットワークの分布構造}

これらの事業所はその殆どが台東区北部エリアに立地している。 地域内全体としてどのような取引の流れがあるのかを把握するため、 これらを住宅地図上に落として分析を実施した。Fig. 6 は 1970 年の 部門別の事業所分布を表している。既往研究による指摘と同様に、 南から北へ向かって、卸売業者から加工・製造業者へと広がりを見 せている。特異な点としては、靴製造業と靴卸業の間の浅草 $6 丁$ 目、 山谷堀の付近に皮革製造販売業が集積している点、および附属材料 はエリア内での固まった集積は見られず大通り沿いに散らばって立 地している点が挙げられる。 


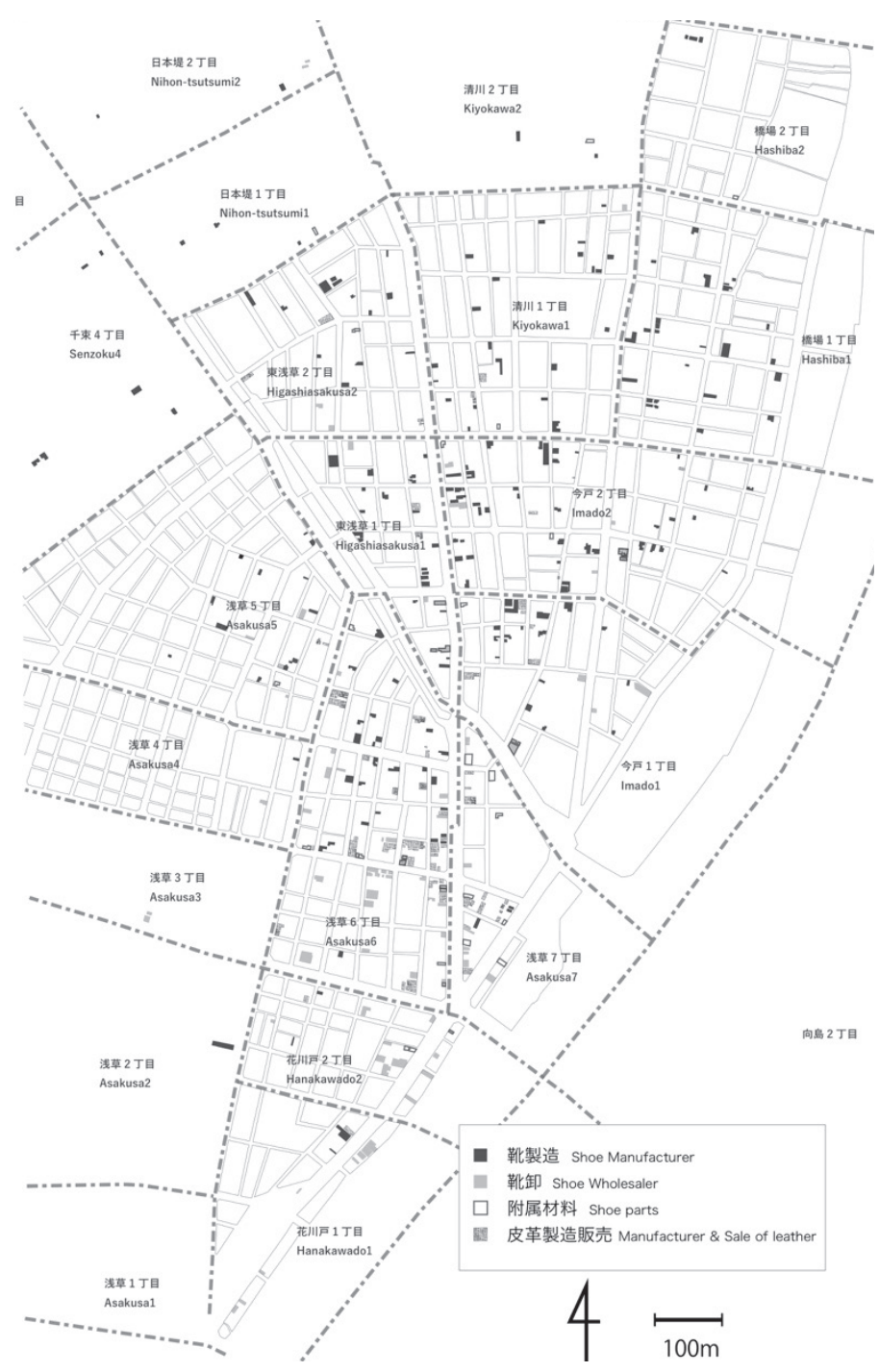

Fig. 6 Distribution of Leather \& Shoe Establishments by Division in 1970

\section{3. 3. まとめ}

これらの結果より、1970 年の台東区の皮革・靴関連産業は主に台 東区北部エリアにおいて集積しており、大きく捉えると以下の Fig. 7 のような取引の動きが形成されていたことが確認できた。ま た、それに伴う人・情報・モノの動きがあったことが予想できる。

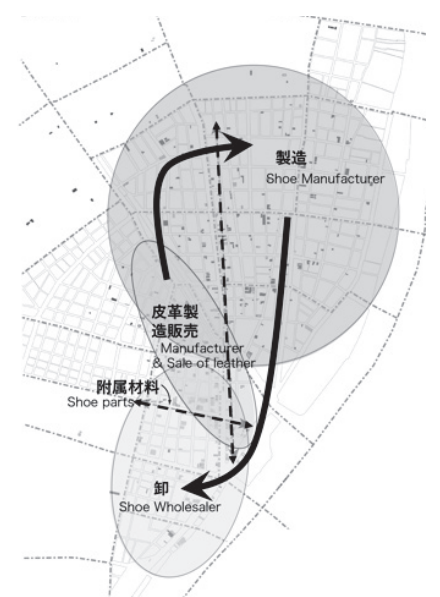

Fig. 71970 Area Dealings flow

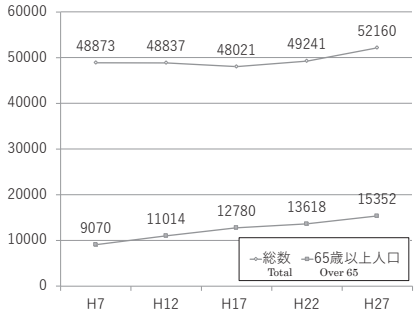

Fig. 9 Population of target area

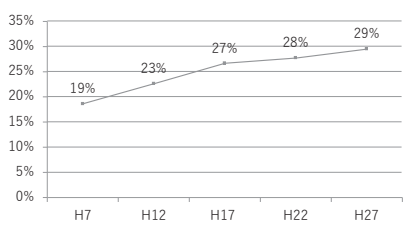

Fig. 10 Aging Rate of Target area

\section{3. 対象地の概要}

\section{1. 対象地の立地と位置付け}

本研究では、台東区景観計画に於いて台東区北部エリアとして指 定されている 20 町丁目注 ${ }^{5)}$ に履物問屋街のメインストリートを持つ 花川戸 $1 \cdot 2$ 丁目を加え 22 町丁目 (Fig. 8 の太線の範囲)における皮 革関連事業所を研究対象とする。

本対象地は、南千住駅と浅草駅の中間に位置し、駅まで少し距離 があること、平坦な地形であることから、業務・生活などの用途で 自転車を日常的に利用寸る人が多い。歴史的には江戸時代の墨引線 の境界と概ね一致しており、街道沿いの微高地を中心にして寺社や 町人地が形成されてきた。またエリアの中心を走る山谷堀(現在は暗 渠化されて緑道となっている)を中心として遊郭や歌舞伎座などの 文化象徴的な空間が形成されてきた地域でもある。皮革産業も近世 よりこの地に集積していた。

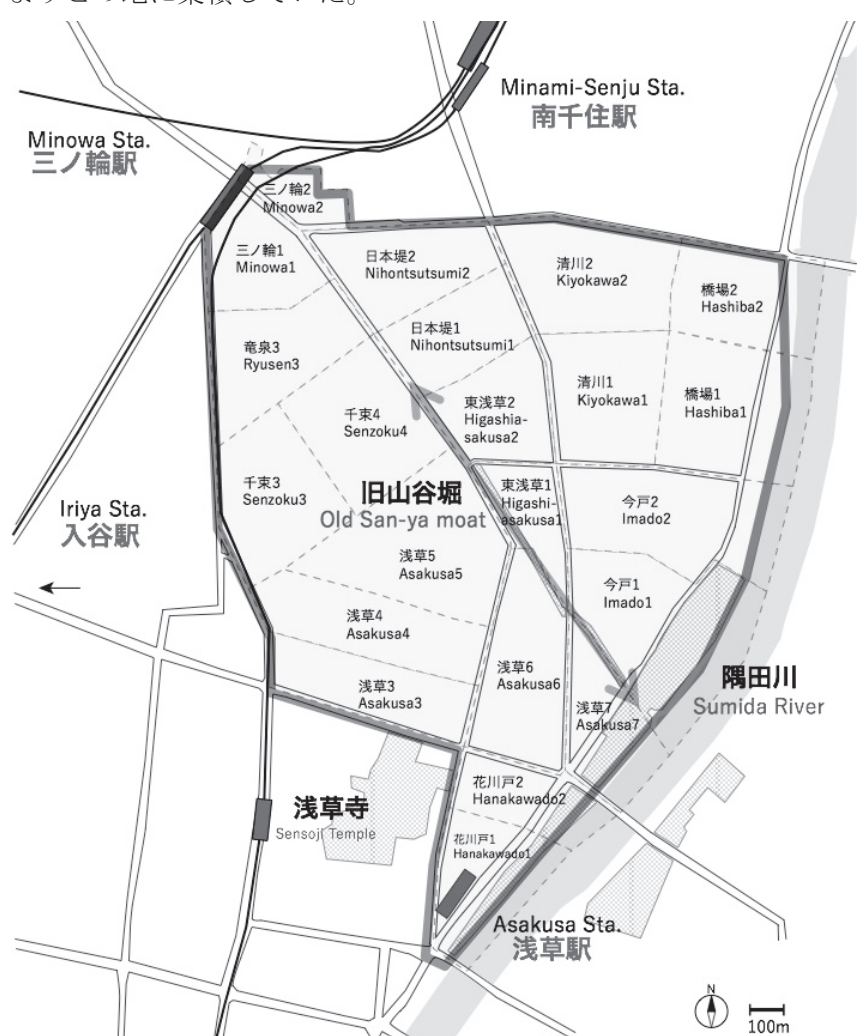

Fig. 8 Location of the Northern Taito-ku and the Scope of Target Area

\section{2. 人口・行政政策}

人口は平成 17 年までは減少傾向にあったが、現在は都心回帰に 伴い増加に転じている(Fig. 9)。今後の更なる住宅地化に伴う開発な どが予想される。また老年人口密度は台東区の他のエリアと比較し て高く、高齢化率も年々上昇している(Fig. 10)。所在する台東区の 中でも比較的低層かつ小規模に職住が混在したエリアとして位置付 けられ、生活圈として居住地域の性質を強める方針が出されている。 用途地域は、一部の地域を除き注 ${ }^{6}$ 主には 1970 年当時が商業地域、 2016 年現在は商業地域及び近隣商業地域で容積率は 400 から $500 \%$ 程度、また山谷堀北部は特別用途地域「第二種中高層階居住専用地 区」に指定されている。

また一方で卸売・製造業を中心とした地場産業振興も注目されて おり、伝統的地場産業継承のため 1972 年には「製くつ科」を有する 
東京都立城東職業能力開発センター台東分校が開設され 1983 年の 東京都立皮革技術センター条例が施行、また 1991 年には東京都台 東区中小企業振興に関する基本条例が施行、2009 年にはインキュベ ーション施設である浅草ものづくり工房開設されるなど、伝統技術 や事業の継承、新規創業を促寸産業施策が実施されてきた。

「住・商・工」混在の特性から、今後小規模な地場産業基盤を保 ちつつ如何にして住居機能を混在させていくかが問われている。

\section{4. 皮革関連産業構造の変遷から見た台東区北部地域の地域産業} 空間構造（台東区北部における製造空間の商業化）

\section{1. 既往研究における東京都皮革関連産業の歴史的立地移動論}

東京都における皮革関連産業のマクロレベルでの立地移動の変遷 は、経済地理学を中心として 1970 年代頃までの整理がある。

近世浅草 (山谷堀北部) を中心として特権的に集積していた皮革関 連産業注7) は、明治期の文明開化並びに自由化・軍需産業化に伴って 製靴業が発展していった。

しかし、明治中期には東京都市部の市街地拡大に伴う衛生面など の見地による機能分離の流れから、原材料などの一次加工工程を司 る製造部門が市外への移転を余儀なくされ、墨田及び荒川地域など 更に外縁部へ転出することとなった。注8)一方で、靴商等の資本家や 引き合い機能は規制を受けず、浅草に残った。
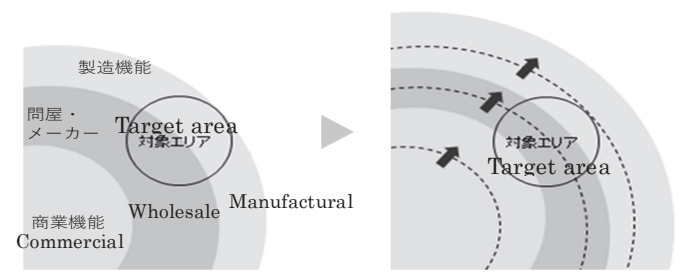

Fig. 11 Transition of Leather Establishments Distribution in Northern Taito-ku

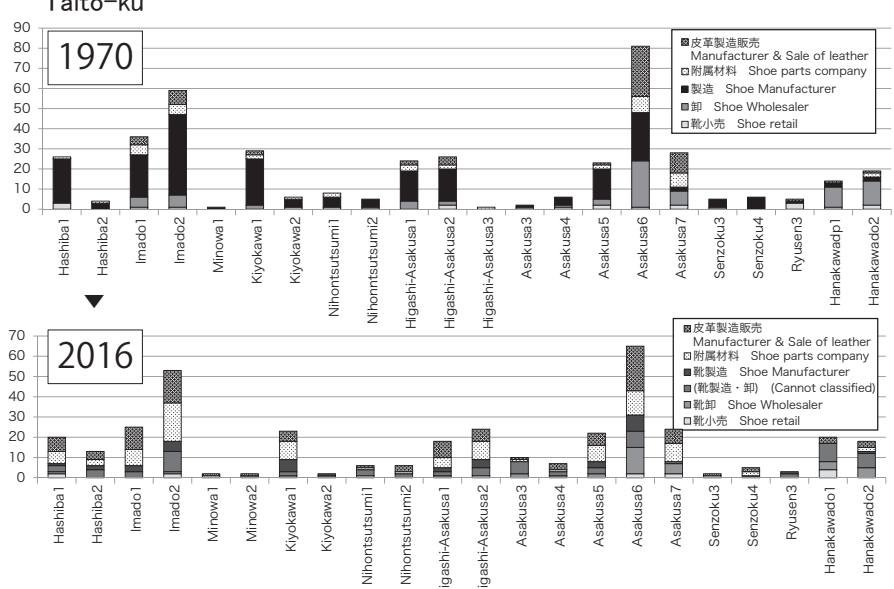

Fig. 12 Diagram of Commercialization to the Outer Edge

Table 2 The Number of Leather Establishments in Taito-ku; 1970/2016

\begin{tabular}{|c|c|c|c|c|c|c|c|}
\hline 1970 & $\begin{array}{l}\text { 彯小茪 } \\
\text { Shoe } \\
\text { retail }\end{array}$ & \multicolumn{2}{|c|}{$\begin{array}{c}\text { 花缷 } \\
\text { Shoo Wholesaler }\end{array}$} & $\begin{array}{c}\text { 当都造 } \\
\text { Shoe } \\
\text { Manufacturer }\end{array}$ & Manufacturer \& & $\begin{array}{l}\text { trampin } \\
\text { Shoeparts } \\
\text { cospany }\end{array}$ & total \\
\hline All of Taito Ward & 89 & \multirow{2}{*}{\multicolumn{2}{|c|}{$\begin{array}{c}85 \\
78(92 \%)\end{array}$}} & 222 & 44 & 66 & 506 \\
\hline North of Taito Ward & $21(24 \%)$ & & & $215(97 \%)$ & $42(95 \%)$ & $58(88 \%)$ & $414(82 \%)$ \\
\hline 2016 & \begin{tabular}{|l|} 
鞀小志 \\
Shoe \\
retail
\end{tabular} & 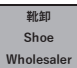 & 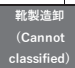 & 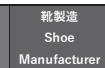 & 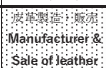 & $\begin{array}{l}\text { Artide } \\
\text { Shoe parts } \\
\text { company }\end{array}$ & total \\
\hline 策帆料/Shoe parts & & & & & $\frac{98}{98}$ & & 98 \\
\hline 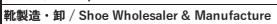 & & 43 & 88 & 41 & & & 172 \\
\hline 酶佔 / Shoes shop & 70 & & & & & & 70 \\
\hline 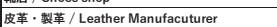 & & & & & & 68 & 68 \\
\hline 皮革材料 / Leather parts & & & & & & 17 & 17 \\
\hline \begin{tabular}{|l} 
革䗲品卸 / Leather goods Wholesaler \\
\end{tabular} & & & & & & 49 & 49 \\
\hline 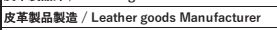 & & & & & & 63 & 63 \\
\hline All of Taito Ward & 70 & 43 & 88 & 41 & 98 & 197 & 537 \\
\hline North of Taito Ward & $15(21 \%)$ & $36(84 \%)$ & $73(83 \%)$ & $38(93 \%)$ & $97(99 \%)$ & $111(56 \%)$ & $370(69 \%)$ \\
\hline
\end{tabular}

近代化の過程でこれらの大規模な立地移動によって商工分離が達 成され、現在の地域間の機能分化構造及び台東区北部地域の商業化 が起こってきた。その概念図をFig. 11 に示す。

\section{2. 台東区北部における皮革関連産業の立地変遷}

本研究が焦点を当てている高度成長期から現代までの変化を調心゙ るために、対象地における 2016 年の皮革関連産業事業所リス卜を タウンページから抽出して作成した。またそのデータをもとに、1970 年当時の部門に当てはめて件数を比較したものをTable. 2 に示す。

外の種目と比べて製造業者の割合が急激に減っていることがわか る。対して、附属材料や皮革の製造販売は増加が見られる。よって、 全体としての事業所の総数はあまり変化が見られない。皮革製造販 売」を除いた靴業者の小売・製造・卸・附属材料で見ると、総数は 440 件から 340 件と 100 件近い減少が見られることがわかる。

次に Fig.12 において部門別の事業所の町丁目毎の分布とその変 化を示した注9)。1970 年には区内事業所の約 $82 \%$ が集積していた台 東区北部地域においては、特に製造業者が減少し、附属材料・皮革 製造販売の業者が増加している。対象エリア内で移転が確認できた 事業所の内、1970 時点で「製造」業者だったものが 2016 に「靴材 料」へと転換が確認できた事例は 1 軒しかないことから注 ${ }^{10)}$ 、事業 所の業務内容が変更されたのではなく、業務内容の異なる新規事業 所が参入したと考えるのが妥当であると考える。集積地の多くが製 造・小売もしくは卸の色が強いのに対して、中間に位置する浅草 6 . 7 丁目では分野が満遍なく分布している事がわかる。

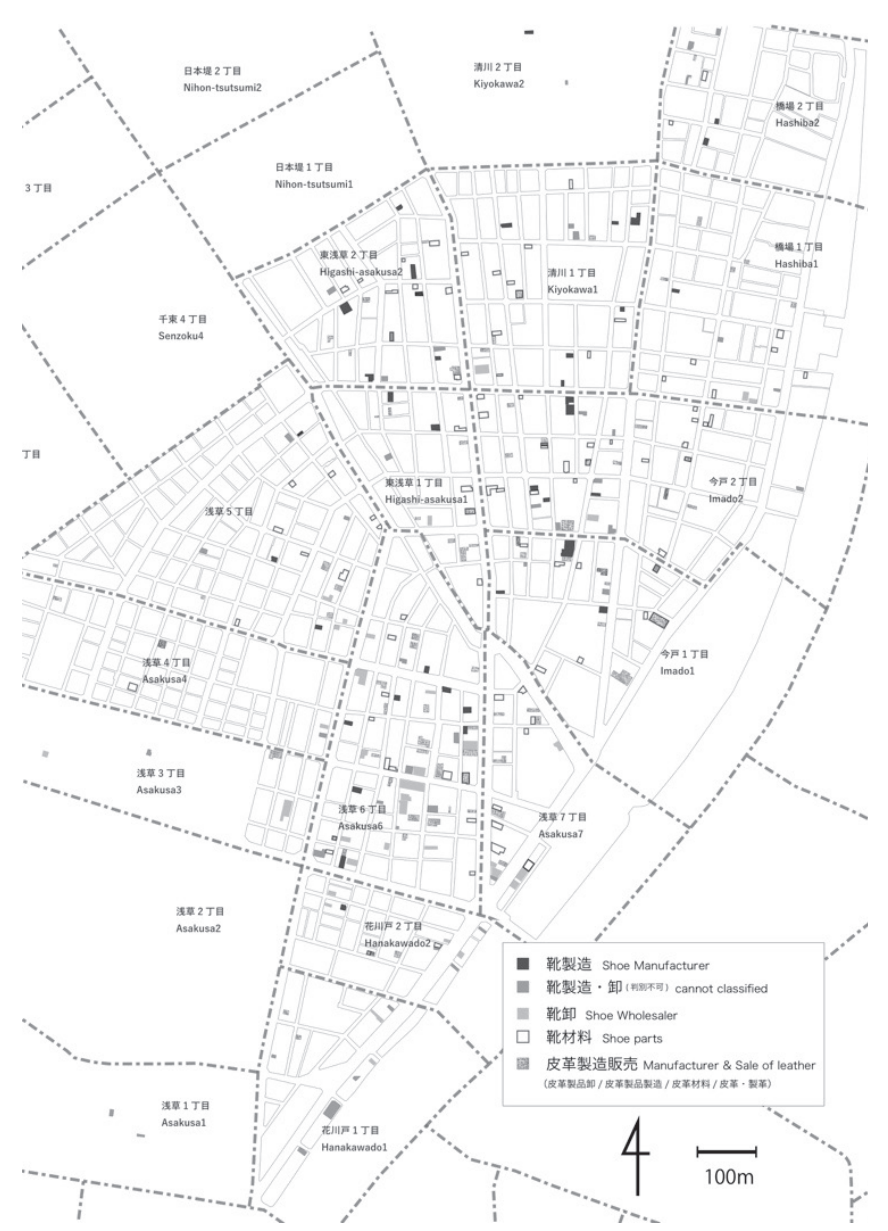

Fig. 13 Distribution of Leather \& Shoe Establishments by Division in 2016 


\section{3. 皮革関連産業の立地変遷から見る地域空間構造}

続いて 2016 年における事業所の立地傾向を探るため、住宅地図 上にその位置関係を落とした図を Fig.13 に示す。Fig.6 で示した 1970 年時分布と比較すると、以下のような特徵の違いが見られる。

・ 1970 : 業種毎の棲み分けが強く、エリア中央の山谷堀を中心 として北部が製造空間と成っており、南部の花川戸エリアに 卸問屋が集積していることがわかる。また、皮革製造・販売 は山谷堀の南の浅草 $6 \cdot 7$ 丁目に多く集積し、附属材料は大通 り沿いを中心として分散して立地している。

- 2016 : 山谷堀の北部に靴材料の事業所が多く集積し、製造及 び皮革製造販売がエリア中に分散する形で面的に広がってい る。山谷堀南部の浅草 6 丁目を中心として卸問屋が集積して いるが、北部にもまばらに立地していることがわかる。

以上を踏まえて 1970 年から 2016 年における変化を整理すると、 一山谷堀北部が製造業者集積地から附属材料業者集積地へと変化 一南から北にかけての同心状構造が平行移動する形で北に移動 - エリアにおいて小売店の増加は見られない

とまとめることができ、エリア全体での産業立地が北側に平行移 動し、山谷堀周辺及び北側を中心として製造空間を中心とした産業 構造が解体し、商業化(但し主に B to B の対業者店舗であると想定 される)が発生していることが判明した(Fig.14)。注11)
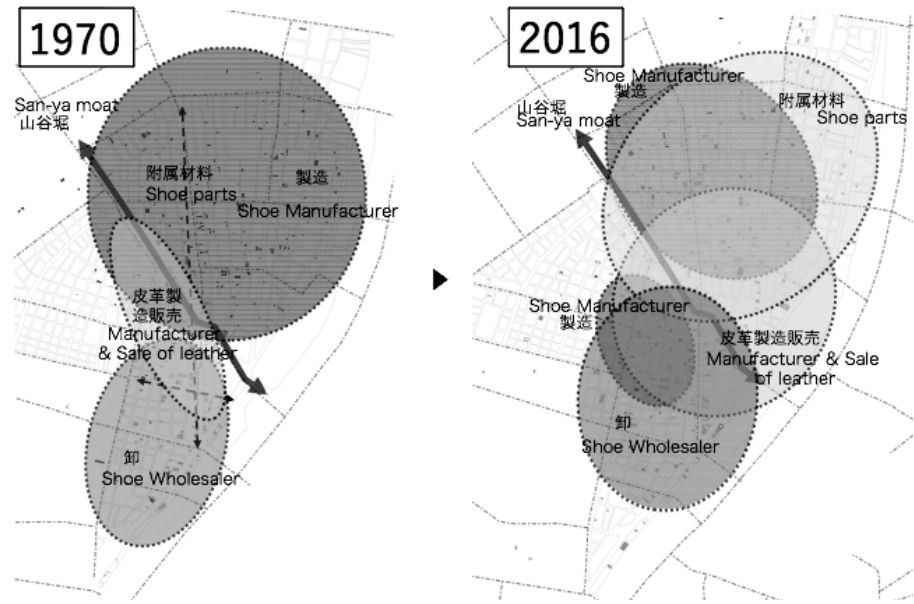

Fig. 14 Diagram of the Regional-Industrial Structure Transition in Northern Taito-ku

\section{5. まとめ}

\section{1. 取引関係と立地から見た 1970 年当時の地域産業空間構造}

1970 年当時は靴製造業者の割合が最も多く、地域産業空間構造は 南から順に卸、皮革製造販売、製造の順で南北に同心円状に業種毎 の立地の棲み分けが存在したことが明らかとなった。取引関係の動 きを見ると、当時はエリア内近距離間での取引の割合が高く、中心 を走る山谷堀が分布の境界として機能していたことが分かった注 ${ }^{12)}$ 。

\section{2. 台東区北部の地域産業空間構造の形成プロセス}

競争優位性も高いと言われており、事業所の数に大きな変動は見 られなかった 1970 年から 2016 年にかけての台東区北部の皮革関 連産業は、産業構造の観点から見てみると付属材料などの製造業者 が減少し、入れ替わるようにして附属材料・皮革製造販売の事業者 が分散的な立地で増加していることが判明した。また地域産業構造
の観点からは、山谷堀北部を中心とした製造空間の解体が見られ、 商業化が発生するなど著しく変化を遂げていることが判明した。事 業所数の変動だけでは表面化しない細かい業種の変化や立地移動を 繰り返しながら、同心円状の構造を維持しつつ産業集積地としての 実態を保っていることがわかった。

\section{3. 都市部職住混在空間の考察へ向けて}

本稿では、皮革関連産業の変化から台東区北部地域の地域産業空 間構造の変遷を明らかにした。ところで職住混在地としての本対象 地の都市空間は、この地域産業空間構造の変化をどのように受容し、 変容してきたのだろうか。その疑問に答えるべく、対象地における 現在の空間実態を調査し、本稿で整理した地域産業空間構造と重ね 合わせた職住混在空間に関する考察を、次稿では取り上げる。

\section{謝辞}

調査に尽き、対象地並びにその周辺の公的機関・事業者・関係者 の方々に多くのインタビュー並びに情報提供の御協力をいただいた。 皆様ご多忙の中、地域に関する内容や産業の仕組みを丁寧に教えて いただいた。この場を借りて感謝の意を示したい。

\section{参考文献}

1) NOHARA, T.: Study on Planning Concepts and actual Developmentof Urban Industrial Spaces in Japan- The Relationship of Productive Spaces and Living Spaces, Doctoral dissertation, The University of Tokyo, 2009

野原卓：日本の工業都市空間における計画概念とその実践的展開に関する 研究-生産空間と生活空間の関係性に着目して, Doctoral dissertation, 東 京大学, 2009

2) IDE, S.: DISTRIBUTION OF CONSUMER GOODS INDUSTRIES AND MANUFACTURING STRUCTURE IN TOKYO, Geographical Review of Japan, Vol.39, No.11, pp. 730-743, 1966 (in Japanese) 井出策夫：大都市日用消費財工業の地域構造，地理学評論, Vol. 39, No. 11, pp. 730-743, 1966

3) TAKEUCHI, A.: Development and Conditions of Location of Tanning Industry Quarters in Tokyo, New Geography, Vol. 10, No. 3, pp. 27-38 1963 (in Japanese)

竹内淳彦，北村嘉行：東京における製革業地域の形成-生産地域の形成と存 続上の諸問題, 新地理, Vol. 10, No. 3, pp. 27-38, 1963

4) OHTANI, T.: PETTY SELF-SUPPORTING MAKERS IN THE DOWNTOWN OF TOKYO, Geographical Review of Japan, Vol. 46, No. 9, pp. 583-599, 1973 (in Japanese)

大谷猛夫：東京都足立区の本木における皮革工業と家具工業についての考 察一巨大都市下町地域の零細工業の存在形態-, 地理学評論, Vol. 46, No. 9, pp. 583-599, 1973

5) YAMAMOTO, S.: The Development of High Value-added Production Systems in the Leather Shoe-making Industry in Taito-ku, Tokyo, Geographical Review of Japan, Vol. 78, No. 4, pp. 179-201, 2005 (in Japanese)

山本俊一郎：東京都台東区靴産地における高付加価值生産システムの構築, 地理学評論, Vol. 78, No. 4, pp. 179-201, 2005

6) TAKAHASHI, S.: Tokyo-to Taito-ku Asakusa-tiiki no hikakukanrensangyo ni okeru aratana ugoki, Co-operative finance for commerce and industry, Vol. 63, No. 4, pp. 5-20, 2013 (in Japanese) 高橋慎二：東京都台東区・浅草地域の皮革関連産業における新たな動き-若 手職人・クリエイターへの支援体制の実際（特集 地域における産業・中 小企業の新たな動き (その 1)), 商工金融, Vol. 63, No. 4, pp. 5-20, 2013

7) MIYADERA, Y.: A Case Study of the Influences of Free Trade in a Local Industry: From a Survey of the Leather Footwear Industry in Asakusa, Bulletin of the Faculty of Social Welfare - Iwate Prefectural University, Vol. 17, pp. 35-42, 2015 (in Japanese) 宮寺良光：自由貿易化に伴う地場産業衰退に関する事例分析-浅草地域の革 
製履物製造業の調査を踏まえて, 岩手県立大学社会福祉学部紀要,Vol. 17, pp. 35-42, 2015

8) Ministry of Economy, Trade and Industry: Census of Manufactures, 2014 (in Japanese), http://www.meti.go.jp/statistics/tyo/kougyo/result2.html(accessed2017-7-13)

経済産業省：工業統計調査, 2014

9) Zenshin: Shoe Industry Directory ver. 1970, 1969 (in Japanese) ぜんしん：靴産業名鑑 1970 版, 1969

10. Town Page -2016 Arakawa Ward ver., 2016 (in Japanese) タウンページ-2016 年荒川区版, 2016

11) PAK Aviation: All Housing Guide Map -Tokyo, Osaka, Nagoya,1970 (in Japanese)

公共施設地図航空株式会社：公共施設地図航空-全住宅案内地図帳 東京都 大阪府名古屋, 1970

12) Zenrin: Zenrin Residential Map -Tokyo ,2016.7 (in Japanese) ゼンリン: ゼンリン住宅地図, 東京都, 2016.7

13) SHIMOMURA, Y: Cultural Production in the Old Industrial Inner City, The Annals of Japan Association for Urban Sociology, Vol. 2015, No. 33, pp. 88-104, 2015 (in Japanese)

下村恭広：都心製造業集積地域の文化的生産，日本都市社会学会年報, Vol 2015, No. 33, pp. 88-104, 2015

14) Taito-City: Taito Landscape planning, 2011.12 (in Japanese) 台東区：台東区景観計画, 2011.12

15) Statistics Bureau, Ministry of Internal Affairs and Communications: National Census, 1995 (in Japanese), http://www.estat.go.jp/SG1/estat/GL08020103.do?_toGL08020103_\&tclassID=00000 $1052675 \&$ cycleCode $=0 \&$ requestSender $=$ search $($ accessed $2017-7-15)$ 総務省統計局: 平成 7 年国勢調査結果-小地域集計, 1995

16) Statistics Bureau, Ministry of Internal Affairs and Communications: National Census, 2000 (in Japanese), http://www.estat.go.jp/SG1/estat/List.do?bid $=000001053233 \&$ cycode $=0$ (accessed 2017 $-7-15)$

総務省統計局: 平成 12 年国勢調査結果-小地域集計, 2000

17) Statistics Bureau, Ministry of Internal Affairs and Communications: National Census, 2005 (in Japanese), http://www.stat.go.jp/SG1/estat/GL08020103.do?_toGL08020103_\&tclassID=00000 1053669\&cycleCode $=0 \&$ requestSender $=$ search $($ accessed 2017-7-15) 総務省統計局：平成 17 年国勢調査結果一小地域集計, 2005

18) Statistics Bureau, Ministry of Internal Affairs and Communications: National Census, 2010 (in Japanese),

http://www.stat.go.jp/data/kokusei/2010/index.htm (accessed2017-7-15) 総務省統計局: 平成 22 年国勢調査結果-小地域集計結果

19) Statistics Bureau, Ministry of Internal Affairs and Communications: National Census, 2015 (in Japanese),

http://www.stat.go.jp/data/kokusei/2015/kekka.htm (accessed2017-7-15) 総務省統計局: 平成 27 年国勢調査結果-小地域集計結果

20) International Geographical society: Tokyo city planning map, 1965 (in Japanese)

国際地学協会: 東京都市計画図-併衛星都市図集 昭和 41 年度新版 用途地 域編，台東区, 1965

21) Taito-City: Taito City Urban Planning Master Plan, 2016 (in Japanese)

台東区: 台東区都市計画マスタープラン, 2006

22) Taito-City: Taito City Industry Promotion Plan, 2017 (in Japanese) 台東区：台東区産業振興計画, 2017

23) Leather industry History Compilation Committee: "Hikakusangyoenkakushi” (History of Leather Industry), 1959 (in Japanese) 皮革産業沿革史編纂委員会 : 皮革産業沿革史, 東京皮革青年会, 1959

24) Taito-City: Taito City history volume 3, 2002 (in Japanese) 東京都台東区：台東区史通史編III 下巻, 2002

25) Tokyo City: "Tokyoshishiko,shigaihenn"(History of Tokyo city), the city volume, No.83, pp 242-245, 1992

東京都：魚獣化製場取締規則，東京市史稿市街篇第 83, pp 242-245, 1992
注

注 1) 取引先が相互に対応していない場合もあるため、本稿ではネットワー クの上ですべて部門と関係を持ち、統括的な立ち位置にある台東区内の 「靴製造業者」 222 件が示している「仕入先」及び「販売先」事業所をも とに分析を実施した。同じ名称が 2 つあり判別が不明なもの、取引先が記 入されていないところも存在し、数值はそれらを省略したものを示すため、 実際には更に大きな取引が行われていたものと考えられる。また「附属材 料」と重複がある事業所に関しては、その取り扱い品目等から判断し「靴 卸」もしくは「皮革製品製造」としてカウントしているが、兼業的に附属 材料の販売を行っていた事業所が複数あったことが推測できる。

注 2) 1970 年と 2016 年に同じ項目の事業所データは存在せず、1970 年の部 門の枠組みで 2016 年の内容を整理した。1970 年のデータは『1970 年靴産 業名鑑』における「皮革の製造販売」「附属材料」「全国靴製造業者」、 「全国靴卸業者」(以下靴卸)、「全国靴小売業者」の項目を利用し、以下の 対応関係のもとで、2016 年タウンページにおける情報を整理した。 1970 : 「皮革の製造販売」 $\Leftrightarrow 2016$ : 「皮革・製革」「皮革材料」「皮革製 品製造」「皮革製品卸」/1970：「附属材料」 $\Leftrightarrow 2016$ ：「靴材料」/ 1970 ： 「全国靴製造業者」・「全国靴卸業者」 $\Leftrightarrow 2016$ ：「靴製造・卸」/ 1970 : 「全国靴小売業者」 $\Leftrightarrow 2016$ : 「靴店」

ここで、更に以下の 3 つのデータを用いて、タウンページの「靴製造・卸」 の部門に掲載されていた事業所の分類を実施した。

○東京都靴卸協同組合名簿(組合 HP 参照)/ ○東都製靴工業組合企業名簿(組 合 HP 参照)/○靴のフリーペーパー「シューフィルザッツ」第 23 号(2009 年 7 月 1 日)「浅草靴産業地図」(組合名簿と「浅草靴産業地図」の内容が異 なる場合組合の内容を優先)

注 3）図では住宅地図上で事業所の名称と住所が確認できたもののみ着色。

注 4）但し、内職・主婦層の参入は複数の論文で報告されており、また筆者自 身も現地において事業者より証言を得ている事象であるが、データ上の数 值として反映されないため実態が掴めていないのが現状である。

注 5）橋場 $1 \cdot 2$ 、今戸 $1 \cdot 2$ 、三八輪 $1 \cdot 2$ 、清川 $1 \cdot 2$ 、日本堤 $1 \cdot 2$ 、東浅草 $1 \cdot 2$ 、浅草 $3 \cdot 4 \cdot 5 \cdot 6 \cdot 7$ 、千束 $3 \cdot 4$ 、竜泉 $3($ 丁目)

注 6）橋場二丁目・清川二丁目地区の準工業地域の一部ならびに日本堤二丁目 の第二種特別工業地区が 2016 年には近隣商業に変更、浅草 7 丁目地区の 住居地域指定の一部が商業地域に組み込まれている。

注 7）以前は日本橋にも集積があった旨が竹内(1963)により報告されている。

注 8） 1892 年には警視庁が「魚獣化製場取締規則」を制定し、該当部門は 10 年以内の市外一の移転を余儀なくされた。立地規制に関しては諸説あり、 当時の政府が具体的な移転先まで指定があったか否かは明らかではないが、 台東区史では警視庁が市外に移転先を指定していた旨が記載されている。

注 9）但し、数值のない町丁目は除してある。

注 10）但し、登記情報ではなく事業所名称のみの照合であるため、他に業種 転換を行なっている事業所が存在する可能性は否定できない。

注 11）立地移動並びに業種の変化の主な要因に革製履物製造業の衰退の影響 が考えられ、その時代背景として市場開放に伴う国外からの輸入量増加、 合成皮革技術の発達、原皮価格の変動、消費者の志向の変化等が挙げられ る。また、竹内(1963)等の既往研究で報告があるように製造事業者は大資 本メーカーとその下請けの家内業的な零細企業に二分化しており、特に市 場の変化の煽りを受けや寸い小規模業者が打撃を受けたと同時に、山本 (2005)で指摘されているように商業地域等の用途地域指定に伴い大規模な 工場の新設が不可能であった点が、地域産業空間構造の変化に影響を与え たと推測される。また、行政施策も含めた現在の産業構造の転換の中での 高付加価值商品化や自社ブランド化推進などの動きは、商業化の文脈から 考えると秩序に沿った動きとも捉えられ、同心円状の地域産業空間の更な る外縁化を遂げている過渡期と見ることができるだろう。しかし一方で、 製造工程の海外依存等によりその構造が内部構造だけでは語れなくなりつ つあることも事実であり、徐々に秩序が崩れていく可能性も考えられる。

注 12）併せて本地域の職住混在性の高さを鑑みると、顔が見える近い距離感 での人間関係が、地域コミュニティ並びに産業ネットワークの 2 つのレイ ヤーによって重層的に形成されていたであろうことが予想できる。 


\title{
REGIONAL-INDUSTRIAL STRUCTURE IN NORTHERN TAITO-WARD FROM THE VIEWPOINT OF TRANSITION OF LEATHER INDUSTRY
}

A study on the fact and inheritance of urban Residential-Industrial mixed-use area from the view of Regional-Industrial structure Part1

\author{
Megumi HAMADA*1, Naoto NAKAJIMA*2 and Yukio NISHIMURA*3 \\ ${ }^{* 1}$ Grad. Student, Dept. of Urban Engineering, School of Engineering, The University of Tokyo, M.Eng. \\ *2 Assoc. Prof., Dept. of Urban Engineering, School of Engineering, The University of Tokyo, Dr.Eng. \\ ${ }^{* 3}$ Prof., Graduate school of Kobe Design University, Dr.Eng.
}

Recently developments in the existing urban \& local industry area destroy the local community network and the spatial characteristics, and the local industries are getting weaker according to the change of industrial structure, so that there is a need to make the sustainable urban \& local industry space. Aims to get suggestions for that, this study focuses on the leather industrial area, which has mixed use spaces from modern times in the existing urban area of Tokyo.

The target area, Northern Taito Ward, is an area where the leather industry is located from early modern times which has been dominated the wholesale and secondary processing industry on a Family scale (integration \& specialization of small scale industry). So that individual buildings in which residence and workshop functions are combined have been popular style in this area.

The methodology of this study ("A study on the fact and inheritance of urban Residential-Industrial mixed-use area from the view of Regional-Industrial structure") is to incorporate the perspective of industrial structure with the discussion on the living environments of mixed-use spaces. So that the final goal is to disclose about the spatial characteristics of the target area and the importance of having view point of not only living but also industry networks in the argument on the mixed-used buildings.

As the First step, this paper discusses about the transition of regional-industrial structure in the target area, northern Taito-Ward from high economic growth period to the present in 4 steps.

In the first method, the statistical survey revealed the position of the target area; the northern part of Taito Ward, seen from the leather industry structure. Located in Tokyo, one of Japanese 2 major leather production areas, it is a region where the production of processed products of pigskin (especially shoes industry) is thriving and features a division of labor system.

Secondly, to catch the movement of transactions inside the area, we quantified the business relationships in the lists in 1970 and dropped them on the maps. Within the area, establishments located separately depending on the type of industry as well, and it was found that there was a high-density business relationship at short distance inside the area at that time.

Thirdly, we extracted the leather industrial establishments from the town page and made the current list. And finally, by comparing the location and business relationship of the establishments in 1970 with the current location, we caught the transition of the regional-industrial structure. There was no major change in the total number of leather establishments, but the number of manufacturers declined and the number of affiliated material stores increased. Distribution of the area by the industrial position tends to be distributed, and it turned out that commercialization occurred in the whole area.

In order to disclose that how the spatial elements of this area accepted the change of transactions, and how the influence form the town by appearing in the landscapes, we will investigate the fact situation of urban space of this area and compare the result with the transition of regional-industrial construction. 